\title{
HIGH-PERFORMANCE COMPUTING TECHNOLOGIES OF MODELING AND IDENTIFICATION OF ADSORPTION IN NANOPOROUS SYSTEMS WITH FEEDBACKS FOR GAS PURIFICATION
}

\author{
Mykhaylo Petryk ${ }^{1}$; Oleksandr Khimich²; Dmytro Mykhalyk ${ }^{1}$; \\ Igor Boyko'; Vasil Kovbashyn ${ }^{1}$
}

\author{
${ }^{I}$ Ternopil Ivan Puluj National Technical University, Ternopil, Ukraine, \\ ${ }^{2}$ Glushkov Institute of Cybernetics of NAS of Ukraine, Kyiv, Ukraine
}

\begin{abstract}
Summary. The paper deals with high-performance computing technologies of modeling and identification of adsorption in nanoporous systems with feedbacks for gas purification. Analytical solutions to the problem of non-isothermal adsorption and desorption are based on Heaviside's operational method and Laplace integral transform, but the development of calculations is quite original. Experimental and modeling distributions of moisture and temperatures of gas at the inlet and outlet of the silica beds for each adsorption - desorption phase at different times are presented. The distribution of moisture within the beds for the full dehydrationregeneration cycle is determined.

Key words: high-performance computing technologies, nanoporous systems with feedbacks, adsorption and desorption of gases modelling; Heaviside's operational method; Laplace integral transform.
\end{abstract}

Introduction. The main anthropogenic sources of atmospheric pollutants are the processes by which energy is generated for transport and industry. It has been demonstrated that the transport sector is the emission source that contributes the most to global warming at present, and it will probably remain so in the immediate future [1]. Natural gas is an important source of primary energy. Its use as a motor fuel for transport and other sectors of industry saves liquid petroleum products, significantly improves the atmosphere of cities and slows the process of global warming. This must be in accordance with European Union specifications governing the security and safety of such technical equipment's [2, 3]. Extensive literature is available on common gas dehydration systems including solid and liquid desiccant and refrigeration-based systems $[4,5]$. Currently, adsorption-based processes rely on a technology, which uses high temperatures for the regeneration of the adsorbent $[6,7]$. The main purpose of this study is to specify all the processes along the columns during non-isothermal adsorption and desorption. For the modeling and identification of adsorption systems we have used the Heaviside operational method which is high-performance computing treatment.

Mathematical model of non-isothermic adsorption and desorption in nanoporous solids The modeling of the kinetics of gas adsorption on a microporous adsorbent and the corresponding regeneration is based on our approach [7,8] using a mathematical model that includes mass balance and heat. 


$$
\begin{gathered}
\frac{\partial c(t, z)}{\partial t}+\frac{\partial a(t, z)}{\partial t}+u \frac{\partial c}{\partial z}=D_{\mathrm{inter}} \frac{\partial^{2} c}{\partial z^{2}} \\
-H \frac{\partial T(t, z)}{\partial t}-u h_{g} \frac{\partial T}{\partial z}-Q_{a d s} \frac{\partial a}{\partial t}-\mathrm{X}^{2} T+\Lambda \frac{\partial^{2} T}{\partial z^{2}}=0 \\
\frac{\partial a}{\partial t}=\beta(c-K a(z, t)) .
\end{gathered}
$$

Initial conditions:
a) adsorption:
b) desorption:
$\left.c(t, z)\right|_{t=o}=0$,
$\left.T(t, z)\right|_{t=o}=T_{0}$,
$\left.c(t, z)\right|_{t=o}=c_{0}$,

Boundary conditions:
a) adsorption:
b) desorption:

$$
\begin{aligned}
& \left.c(t, z)\right|_{z=0}=c_{i n}(t), \\
& \left.\frac{\partial}{\partial z} c(t, z)\right|_{z=\infty}=0, \\
& \left.T(t, z)\right|_{z=0}=T_{i n}(t),
\end{aligned}
$$$$
\left.c(t, z)\right|_{z=o}=c_{\text {in }} \text {, }
$$$$
\left.\frac{\partial}{\partial z} c(t, z)\right|_{z=\infty}=0
$$$$
\left.\frac{\partial}{\partial z} T(t, z)\right|_{z=\infty}=0 \text {. }
$$

Methodology of analytical solutions of the adsorption-desorption model. The solution of the system (1)-(6) was obtained using Heaviside's operational method [9]. Applying the Laplace transformation to eq. (1)-(6) one obtains:

$$
\begin{gathered}
\frac{d^{2} c^{*}}{d z^{2}}-u_{1} \frac{d c^{*}}{d z}-q^{2} c^{*}=-\mathrm{F}^{*}, \\
\frac{d^{2}}{d z^{2}} T^{*}-u_{2} \frac{d}{d z} T^{*}-q_{2}^{2}(p) T^{*}=-\mathrm{F}_{2}^{*}(p),
\end{gathered}
$$

Boundary conditions:

a) adsorption:

$$
\begin{aligned}
& \left.c^{*}(p, z)\right|_{z=o}=\frac{1}{p} c_{i n}, \\
& \left.\frac{\partial}{\partial z} c^{*}(p, z)\right|_{z=\infty}=0, \\
& \left.\frac{\partial}{\partial z} T^{*}(p, z)\right|_{z=\infty}=0,
\end{aligned}
$$

where: $u_{1}=\frac{u}{D_{\text {int } e r}}$

$$
u_{2}=\frac{u h_{g}}{\Lambda}
$$

b) desorption:

$$
\begin{aligned}
& \left.\frac{d}{d z} c^{*}(p, z)\right|_{z=\infty}=0, \\
& \left.c^{*}(p, z)\right|_{z=o}=\frac{1}{p} c_{i n}, \\
& \left.T^{*}(p, z)\right|_{z=0}=T_{i n}^{*}(p) .
\end{aligned}
$$


$c^{*}(p, z)=\int_{0}^{\infty} c(t, z) \mathrm{e}^{-p t} d t \equiv L[c], a^{*}(p, Z)=\int_{0}^{\infty} a(t, z) \mathrm{e}^{-p t} d t \equiv L[a], T^{*}(p, z)=\int_{0}^{\infty} T(t, z) \mathrm{e}^{-p t} d t \equiv L[T]$

where $p$ is a complex-value parameter of the Laplace transformation [9].

The solution of eq. (7) with conditions $(9),(10)$ is $[7,8]$ :

$$
c^{*}(p, z)=\frac{c_{i n}}{p} e^{\frac{u_{1}}{2} z} e^{-\omega_{1}(p) z}+c_{0} \frac{1}{K+1}\left[\frac{K}{p}+\frac{1}{p+\beta(K+1)}\right]\left(1-e^{\frac{u_{1}}{2} z} e^{-\omega_{1}(p) z}\right) .
$$

Calculating the Laplace originals in eq. (127), we obtain:

$$
\begin{aligned}
& c(t, z)=c_{0} \frac{K}{K+1} L^{-1}\left[\frac{1}{p}\right]+\frac{c_{0}}{K+1} L^{-1}\left[\frac{1}{p+\beta(K+1)}\right]+\left(c_{i n}-c_{0}\right) e^{\frac{u_{1}}{2} z} L^{-1}\left[\frac{e^{-\omega_{1}(p) z}}{p}\right]+ \\
& +c_{0} \beta L^{-1}\left[\frac{1}{p+\beta(K+1)}\right] * L^{-1}\left[\frac{e^{-\omega_{1}(p) z}}{p}\right] e^{\frac{u_{1}}{2} z},
\end{aligned}
$$

where Laplace original $L^{-1}\left[\frac{e^{-\omega_{1}(p) z}}{p}\right]$ after the calculation of the Bromwich integral is [7,9]:

$$
\mathrm{W}_{c}(t, z) \equiv L^{-1}\left[\frac{e^{-\omega_{1}(p) z}}{p}\right]=\frac{1}{\pi} \int_{0}^{\infty} e^{-\varphi_{1}(v) z} \frac{\sin \left(v t-z \varphi_{2}(v)^{2}\right)}{v} d v+e^{-\frac{u}{2 D_{\text {iner }} z}}
$$

Substituting eq. (14) in eq. (13) we obtain the analytical solution of eq. (1)-(6) which describe the concentration of moisture in the gas phase and adsorbed on the solid:

$$
\begin{gathered}
c(t, z)=\frac{K}{K+1} c_{0}+\frac{c_{0}}{K+1} e^{-\beta(K+1) t}+e^{\frac{u}{2 D_{\text {inter }}} \int_{0}^{t} \mathrm{~W}_{c}^{\text {in }}(t-\tau, z) c_{\text {in }}(\tau) d \tau-c_{0} e^{\frac{u}{2 D_{\text {inter }}} z} \mathrm{~W}_{c}^{0}(t, z)+} \\
+\beta c_{0} e^{\frac{u}{2 D_{\text {inter }}} z} \int_{0}^{t} e^{-\beta(K+1)(t-\tau)} \mathrm{W}_{c}^{0}(\tau, z) d \tau, \\
a(t, z)=\beta \int_{0}^{t} e^{-\beta K(t-\tau)} c(\tau, z) d \tau .
\end{gathered}
$$

where $\mathrm{W}_{c}^{\text {in }}(t, z)=\frac{1}{\pi} \int_{0}^{\infty} e^{-\varphi_{1}(v) z} \cos \left(v t-\varphi_{2}(v)\right) d v, \varphi_{1,2}(v)=\left[\frac{\left(\Gamma_{1}^{2}(v)+v^{2} \Gamma_{2}^{2}(v)\right)^{1 / 2} \pm \Gamma_{1}^{2}(v)}{2}\right]^{1 / 2}$, $\Gamma_{1}(v)=\frac{u^{2}}{4 D_{\text {inter }}^{2}}+\frac{v^{2} \beta}{D_{\text {inter }}^{2}\left(v^{2}+\beta^{2} K^{2}\right)}, \quad \Gamma_{2}(v)=\frac{v^{3}+v \beta^{2}(K+1) K}{D_{\text {inter }}\left(v^{2}+\beta^{2} K^{2}\right)}$.

Similarly, the analytical solution of (1)-(6) which describes the temperature distribution in the adsorbent is [7, 9]: 


$$
\begin{gathered}
T(t, \mathrm{z})=T_{\text {in }}(0) \Phi_{T}^{0}(t, z)+\int_{0}^{t} \frac{d}{d \tau} T_{\text {in }}(\tau) \Phi_{T}^{0}(t-\tau, z)+ \\
+\frac{1}{\Lambda} \int_{0}^{t} \int_{0}^{\infty}\left[H T_{0} \mathrm{H}_{T}(t-\tau ; z, \xi)-Q_{a d s} \beta\left(\mathrm{H}_{T}(t-\tau ; z, \xi)-\beta K \int_{0}^{t-\tau} e^{-\beta K(t-\tau-s)} \mathrm{H}_{T}(\tau-s ; z, \xi) d s\right) c(p, \xi)\right] d \xi d \tau \\
\text { Here } \mathrm{H}_{T}(\tau ; z, \xi)=e^{-\frac{u_{2}}{2}(z-\xi)}\left(\Phi_{T}(\tau,|z-\xi|)-\Phi_{T}(\tau, z+\xi)\right) \\
\Phi_{T}(t, \mathrm{z}) \equiv L^{-1}\left[\frac{e^{-\omega_{2}(p) z}}{2 \omega_{2}(p)}\right]=\frac{1}{2 \pi} \int_{0}^{\infty} \frac{\phi_{1}(v) \cos \left(v t-\phi_{2}(v) \mathrm{z}\right)+\phi_{2}(v) \sin \left(v t-\phi_{2}(v) \mathrm{z}\right)}{\left(\Gamma_{T_{1}}^{2}(v)+v^{2} \Gamma_{T_{2}}^{2}(v)\right)^{1 / 2} d v} \\
\Phi_{T}^{0}(t, z) \equiv L^{-1}\left[\frac{e^{-\omega_{2}(p) z}}{p}\right]=\frac{1}{\pi} \int_{0}^{\infty} e^{-\phi_{1}(v) z} \frac{\sin \left(v t-z \phi_{2}(v)^{2}\right)}{v} d v+e^{-\frac{u}{2 D_{\text {inter }}}}, \\
\Gamma_{2}(v)=\frac{v^{3}+v \beta^{2}(K+1) K}{D_{\text {inter }}\left(v^{2}+\beta^{2} K^{2}\right)}, \quad \phi_{1,2}(v)=\left[\frac{\left(\Gamma_{T_{1}}^{2}(v)+v^{2} \Gamma_{T_{2}}^{2}(v)\right)^{1 / 2} \pm \Gamma_{T_{1}}^{2}(v)}{2}\right]^{1 / 2}, \\
\Gamma_{T_{1}}(v)=\frac{u^{2}+4 \Lambda \mathrm{X}^{2}}{4 \Lambda^{2}}, \Gamma_{T_{2}}(v)=\frac{H v}{\Lambda}, \omega_{2}(p)=\left(\frac{1}{4} u_{2}^{2}+q_{2}^{2}(p)\right)^{1 / 2}, \operatorname{Re} \omega_{2}>0
\end{gathered}
$$

Analysis and simulation. The experimental conditions of the system are presented in [7]. Moisture concentrations of the gas that enters the drying adsorbent column (adsorption phase) during a dehydration cycle are presented in Fig. 1. These variations are due to the minor fluctuations of the gas pressure in the network. The corresponding average moisture at the inlet, $0.175 \mathrm{~g} / \mathrm{m}^{3}$, is used for the simulations.

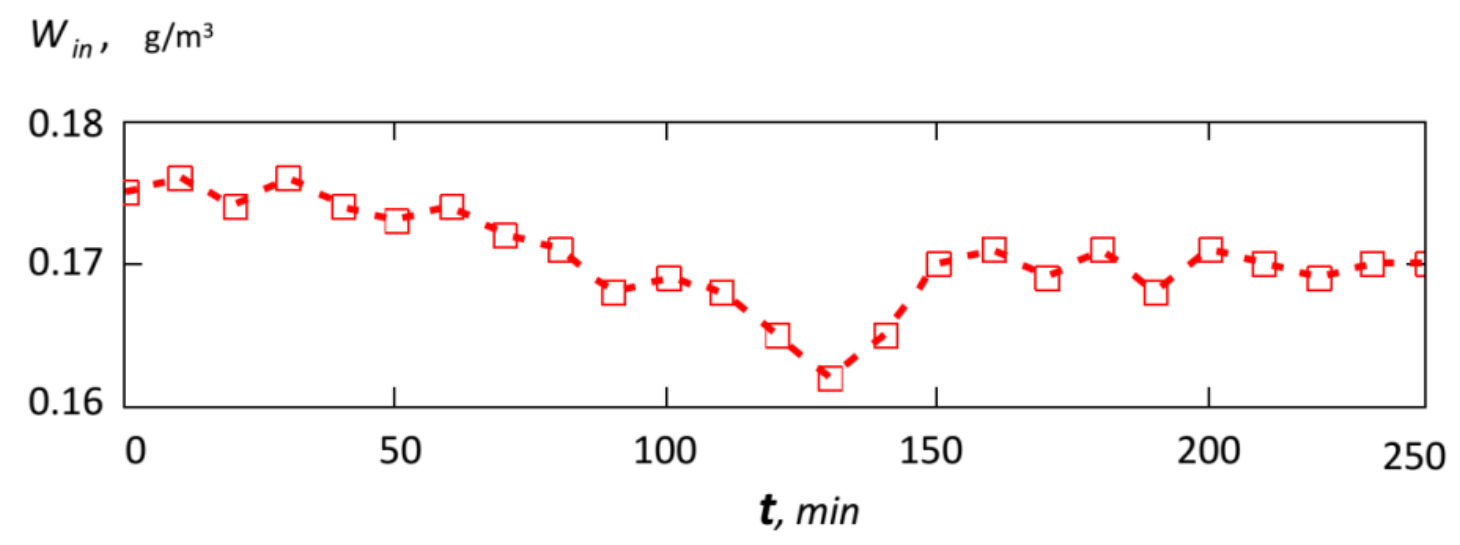

Figure 1. Experimental concentration of gas moisture at inlet of adsorbent column during the adsorption phase

Fig. 2 displays the moisture variations against time of dehydrated gas at the outlet of the adsorbent column. Adsorbent regeneration (desorption phase) is carried out with a small fraction of the dehydrated gas $\left(10 \%\right.$ in our experiments) heated at $125-130^{\circ} \mathrm{C}$. Fig. 3 shows the variation of the temperature near the inlet $T_{i n}\left(T_{1}, T_{2}\right)$ and outlet $T_{\text {out }}\left(T_{3}, T_{4}\right)$ of the column during the desorption phase. 


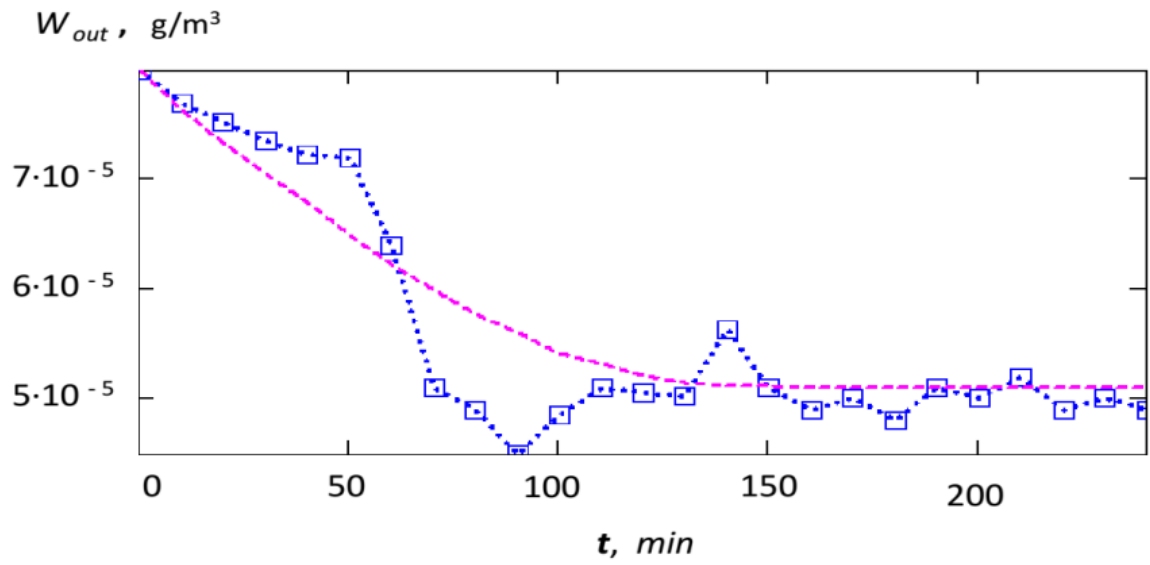

Figure 2. Moisture content of dehydrated gas at the outlet of the adsorbent column (blue square points - experiment; dotted red line - model)

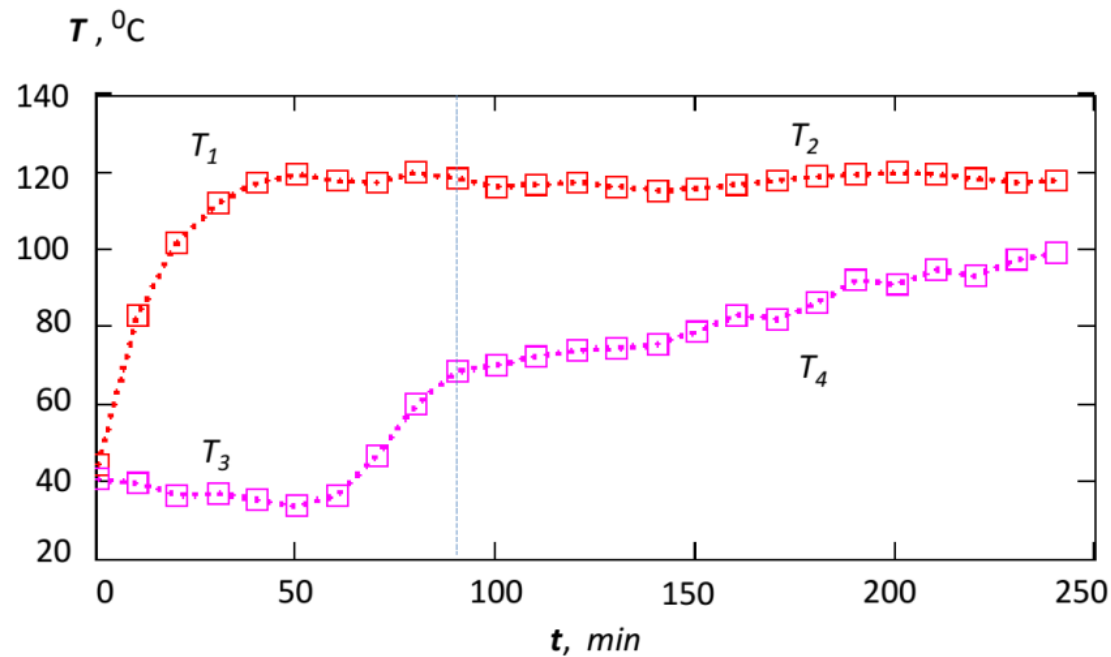

Figure 3. The temperature of gas near the inlet Tin (T1, T2) and at the outlet Tout (T3, T4) of the column of regeneration (squares - experiment, dotted line - model)

$$
w_{r e g}, \mathrm{~g} / \mathrm{m}^{3}
$$

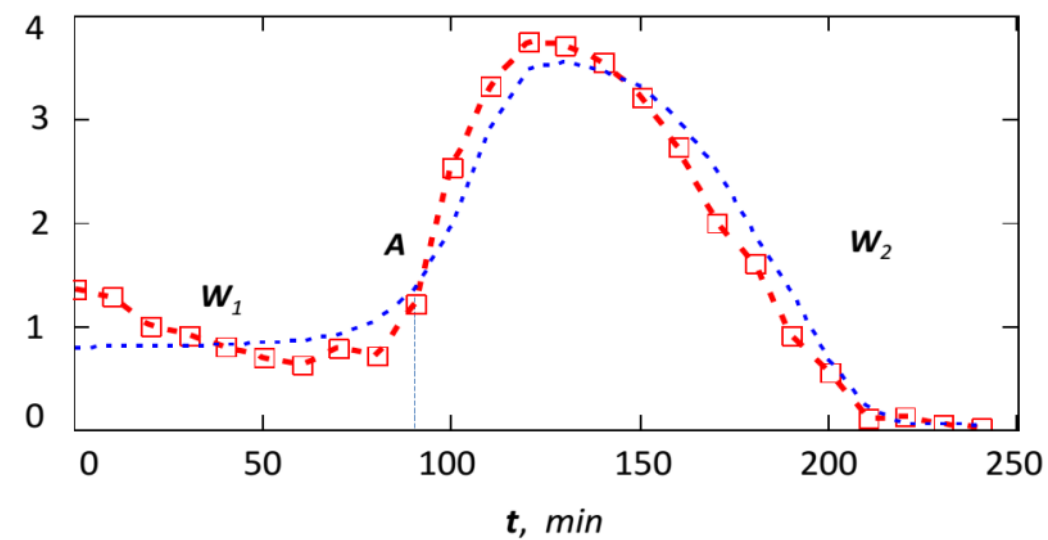

Figure 4. Moisture of the gas at the outlet of the column during the regeneration of the adsorbent during 240 minutes (square red points - experiment, dotted blue line - model) 
The variation of the moisture of the gas at the outlet of the column of regeneration (Fig. 4) shows the kinetics of the internal desorption of the moisture during 240 minutes. Fig. 3 and 4 show that the regeneration process is characterized by two specific periods: the heating of the adsorbent, corresponding roughly to the first 90 minutes (Fig. 4, curves $T_{1}$ and $T_{3}$, Fig. 5, curve $\mathbf{w}_{1}$ ) and the regeneration period (Fig. 3, curves $T_{2}$ and $T_{4}$, Fig. 4 , curve $\mathbf{w}_{2}$ ). Further there is a higher and stable temperature $T_{\text {in }} \approx 120-125^{\circ} \mathrm{C}$ and $T_{\text {out }}$ increases continuously.

Conclusion. Our studies have confirmed the effectiveness of the «adsorptiondesorption» technology for the purification of natural gas used as fuel in extreme climates. After each drying cycle, the residual moisture content of the gas is lower than the maximum allowable value of $0.009 \mathrm{~g} / \mathrm{m} 3$. The solution of the proposed mathematical model for the gas adsorption process on porous solid and its regeneration is based on an original algorithm using the Heaviside operational method and the Laplace transform. These high-performance computing technologies of modeling and identification of adsorption in nanoporous systems with feedbacks can serve as a model for many applications relating to this type of process for the purification of confined atmospheres.

\section{References}

1. Unger N., Bond T. C., Wang J. S., Koch D. M., Menon S., Shindell D. T., Bauer S. Attribution of climate forcing to economic sectors. Proc. Natl. Acad. Sci., 2010. 107 (8). P. 3382-7. https://doi.org/10.1073/ pnas.0906548107

2. Euro 5 and Euro 6 standards: reduction of pollutant emissions from light vehicles. URL: europa.eu/legislation_summaries/environment/air_pollution/128186_es.htm (accessed 5.06.2010).

3. Gandhidasan P., Al-Farayedhi AA, Al-Mubarak AA. Dehydration of natural gas using solid desiccants. Energy 2001, 26. P. 855-868. https://doi.org/10.1016/S0360-5442(01)00034-2

4. Karimi A., Abdi MA. Selective dehydration of high-pressure natural gas using supersonic nozzles. Chemical Engineering and Processing. 2009. 48. P. 560-568. https://doi.org/10.1016/j.cep.2008.09.002

5. Netusil M., Pavel D. Comparison of three methods for natural gas dehydration. Journal of Natural Gas Chemistry. 2011. 20 (5). P. 471-476. https://doi.org/10.1016/S1003-9953(10)60218-6

6. Puertolas B., Navarro M. V., Lopez J. M., Murillo R., Mastral A. M., Garcia T. Modelling the heat and mass transfers of propane onto a ZSM-5 zeolite. Separation and Purification Technology. 2012. 86. P. 127136. https://doi.org/10.1016/j.seppur.2011.10.036

7. Petryk M., Khimitch A., Petryk M. M., Fraissard J. Experimental and computer simulation studies of dehydration on microporous adsorbent of natural gas used as motor fuel. Fuel. 2019. Vol. 239. P. 1324-1330. https://doi.org/10.1016/j.fuel.2018.10.134

8. Sergienko I., Petryk M., Khimith O. N., Mykhalyk D., Leclerc S., Fraissard J. Mathematical Modelling of Diffusion Process in Microporous Media (Numerical analysis and application). National Academy of Sciences of Ukraine. Kyiv, 2014. 196 p. [In Ukrainian].

9. Lavrentiev M. A., Shabat B. V. Methods of theory of functions of a complex variable. M.: Nauka, 1973. 736 p. [In Russian].

\section{Список використаної літератури}

1. Unger N., Bond T. C., Wang J. S., Koch D. M., Menon S., Shindell D. T., Bauer S. Attribution of climate forcing to economic sectors. Proc. Natl. Acad. Sci., 2010. 107 (8). P. 3382-7. https://doi.org/10.1073/ pnas.0906548107

2. Euro 5 and Euro 6 standards: reduction of pollutant emissions from light vehicles. URL: europa.eu/legislation_summaries/environment/air_pollution/128186_es.htm (дата звернення 5.06.2010).

3. Gandhidasan P., Al-Farayedhi AA, Al-Mubarak AA. Dehydration of natural gas using solid desiccants. Energy 2001, 26. P. 855-868. https://doi.org/10.1016/S0360-5442(01)00034-2

4. Karimi A., Abdi MA. Selective dehydration of high-pressure natural gas using supersonic nozzles. Chemical Engineering and Processing. 2009. 48. P. 560-568. https://doi.org/10.1016/j.cep.2008.09.002

5. Netusil M., Pavel D. Comparison of three methods for natural gas dehydration. Journal of Natural Gas Chemistry. 2011. 20 (5). P. 471-476. https://doi.org/10.1016/S1003-9953(10)60218-6

6. Puertolas B., Navarro M. V., Lopez J. M., Murillo R., Mastral A. M., Garcia T. Modelling the heat and mass transfers of propane onto a ZSM-5 zeolite. Separation and Purification Technology. 2012. 86. P. 127-136. https://doi.org/10.1016/j.seppur.2011.10.036 
7. Petryk M., Khimitch A., Petryk M. M., Fraissard J. Experimental and computer simulation studies of dehydration on microporous adsorbent of natural gas used as motor fuel. Fuel. 2019. Vol. 239. P. 1324-1330. https://doi.org/10.1016/j.fuel.2018.10.134

8. Сергієнко І., Петрик М., Хіміч О., Михалик Д., Леклер С., Фрессар Ж. Математичне моделювання дифузійних процесів в мікропористих середовищах (чисельний аналіз та застосування). Національна академія наук України. Київ, 2014. 196 с.

9. Lavrentiev M. A., Shabat B. V. Methods of theory of functions of a complex variable. M.: Nauka, 1973. 736 p. [In Russian].

\title{
УДК 519.7
}

\section{ВИСОКОПРОДУКТИВНІ КОМП'ЮТЕРНІ ТЕХНОЛОГЇ̈ МОДЕЛЮВАННЯ ТА ІДЕНТИФІКАЦІї АДСОРБЦІї В НАНОПОРИСТИХ СИСТЕМАХ ЗІ ЗВОРОТНИМИ ЗВ'ЯЗКАМИ ДЛЯ ОЧИЩЕННЯ ГАЗІВ}

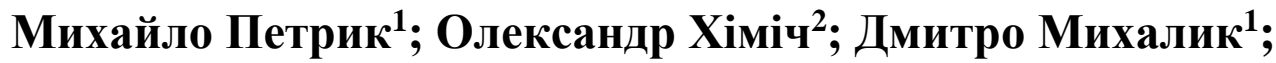 \\ Ігор Бойко ${ }^{1}$; Василь Ковбашин ${ }^{1}$
}

\author{
${ }^{1}$ Тернопільський національний технічний університет імені Івана Пулюя, \\ Тернопіль, Україна \\ ${ }^{2}$ Інститут кібернетики імені В. М. Глушкова НАН Украӥни, Київ, Україна
}

\begin{abstract}
Резюме. Розглянуто високоефективні обчислювальні технології моделювання та ідентифікаціі адсорбиії в нанопористих системах зі зворотними зв'язками для очищення газу. Моделювання кінетики адсорбиії газу в мікропористому адсорбенті та відповідної регенерації опирається на використання математичної моделі, щзо включає баланс маси й тепла. Аналітичні розв 'язки проблеми неізотермічної адсорбиії та десорбиії трунтуються на операційному методі Гевісайда й інтегральних перетвореннях Лапласа, але запропонована методика обчислень є новою. Представлено експериментальні та модельні розподіли вологи й температури газу на вході та виході шару адсорбента для кожної фази адсорбиіїдесорбиії в різні часові інтервали. Визначено розподіл вологи в межах шару для повного ииклу зневоднення - регенерації. Проведені дослідження підтвердили ефективність технології «адсорбиіядесорбиія» для очищення природного газу, щзо використовується в якості палива в екстремальних кліматичних умовах. Після кожного цииклу сушіння залишковий вміст вологи в газі нижче максимально допустимого значення. Варіювання вологи газу на виході з колони регенерації відображає кінетику внутрішньої десорбиії вологи та вказує, щчо процес регенерації характеризується двома специфічними періодами: нагріванням адсорбента й регенерацією періоду. Далі спостерігається вища й стабільніша температура, яка постійно піднімається. Розв'язок запропонованої математичної моделі процесу адсорбиії газу на пористому твердому тілі та його регенерації базується на оригінальному алгоритмі, розробленому з використанням операційного методу Гевісайда та інтегральних перетворень Лапласа. Ця високоефективна обчислювальна технологія моделювання й ідентифікаџії адсорбиії в нанопористих системах зі зворотними зв'язками може слугувати основою для багатьох застосувань, щяо стосуються подібного типу процесів очищення в обмеженому середовищі.

Ключові слова: високоефективні обчислювальні технології, нанопористі системи зі зворотними зв'язками, адсорбиією та десорбиією; моделювання газів; операичійний метод Гевісайда; інтегральні перетворення Лапласа.
\end{abstract}

